Review

\title{
Ecopreneurship and Ecopreneurs: Limits, Trends and Characteristics
}

\section{Cristina Santini}

Department of Human Sciences and Quality of Life Promotion, Università San Raffaele, Via Val Cannuta 247, 00166 Rome, Italy; cristina.santini@unisanraffaele.gov.it

Academic Editor: Iain Gordon

Received: 30 November 2016; Accepted: 18 March 2017; Published: 25 March 2017

\begin{abstract}
The research topic of Ecopreneurship is growing and new questions emerge, whilst others remain unanswered. This paper provides an extensive literature review and aims to highlight research outputs and trends in ecopreneurship. Besides a reflection on the main features, motivations and typologies of ecopreneurs, the paper provides a focus on the relationship between agribusiness and ecopreneurship in order to outline issues that hopefully will be further investigated and extended to other businesses. By following the main trends within the academic debate, the paper provides insights into the defining the distinguishing traits of ecopreneurship when compared to traditional entrepreneurship. The author provides an overview of research issues that could be explored in the future.
\end{abstract}

Keywords: ecopreneurship; ecopreneur; sustainability; agribusiness; ecopreneurial orientation; sustainable orientation

\section{Introduction}

The research field of entrepreneurship covers many issues; ecopreneurship, a niche within entrepreneurship, came into the spotlight during the 1990s and it has attracted scholars' attention. Interest in this research issue keeps on growing; despite this, some research questions are still open. Talking about ecopreneurs means not only dealing with some theoretical problems, but it also invites scholars to reflect on the approach to adopt in research design. This paper presents the main contributions to the study of ecopreneurs and ecopreneurship; a review of selected literature has been performed, following the insights emerging from Hart, 1998 [1] and Jesson et al, 2011 [2]. The paper also examines the boundaries of ecopreneurship and the emerging differences with traditional entrepreneurship. Agribusiness is a breeding ground for ecopreneurship, given the relevant role of resource exploitation and management and the importance of environmentally friendly practices; this paper also investigates the role of ecopreneurs in agribusiness. Focussing on a specific sector leads to a multitude of questions and to a discussion that points out the limits of research and the aspects to be further investigated.

\section{Ecopreneurship and Ecopreneurs}

There is a wide debate on ecopreneurs and ecopreneurship; many definitions of ecopreneurship have been provided by scholars. A first challenge when dealing with ecopreneurship is to find a unique definition of ecopreneurs; this challenge arises firstly because the issue under investigation is complex and secondly because the lack of academic consensus about what constitutes an entrepreneur (Chell et al., 1991 [3]) makes it even harder to define ecopreneurship. The definition proposed by Kirkwood and Walton (2010) [4] is widely employed and it suggests that ecopreneurs are entrepreneurs who found new businesses based on the principles of sustainability. Isaak $(1998 ; 2005)[5,6]$, 
when talking about ecopreneurial organizations, underlines the commitment of the organization itself and Walley and Taylor (2002) [7] highlight that ecopreneurs can be considered as change drivers. Thus, the interest towards ecopreneurship and ecopreneurs has significantly improved the number of academic outcomes; furthermore, environmental issues have been progressively incorporated into texts on entrepreneurship (Schaper, 2002) [8]. Nevertheless, the initiatives undertaken by tertiary institutions have fostered interest in ecopreneurship; Schaper (2002) [8] clearly describes the process that has promoted entrepreneurship by putting together the role of business venturing, start-ups and institutions' involvement.

Academic research somehow reflects the changes happening in ecopreneurship that, from a niche theme, progressively became a wide research issue: If initially ecopreneurs were seen as solitary heroes that were committed to spreading the gospel of a green vision to a naïve marketplace, today they are business people who are determined to gain a reasonable market share in the relatively competitive environment. The work by Shaltegger (2002) [9] clearly underlines that the business for ecopreneurs can have extended boundaries.

Ecopreneurs have some distinctive traits when compared to traditional entrepreneurs; the debate on the existing differences between ecopreneurs and entrepreneurs is far from finding a conclusion. The growth and the evolution of research on ecopreneurship can be "measured" also by the great discussion about ecopreneurship. Today, the situation is different from the one described by Hockerts in 2006 [10]; the author, a decade ago, observed that the term ecopreneurs was mainly used in academic circles. Now, ecopreneurship is a word widely employed and diffused among scholars, institutions, associations and entrepreneurs. There are educational programmes that have been developed by business schools with the aim of promoting ecopreneurship and stakeholder associations are actively involved in facilitating ecopreneurship. There are nonprofit organizations-such as Ecopreneurs for the Climate-that promote ecopreneurial culture and institutions support research projects that aim to promote ecopreneurship. In ecopreneurship, policy makers see a tool for solving the environmental and unemployment crisis (Isaak, 2016 [11]).

All these elements suggest the impact and the relevance of this research issue that was born as a niche and is progressively gaining resonance and importance.

\section{Characteristics}

It is necessary to recall some of the knowledge on entrepreneurship if we want to outline the characteristics of the ecopreneur; our approach follows what has already been done by a relevant number of scholars in the field of ecopreneurship. Research on entrepreneurship is endless; a wide branch of the research has investigated the characteristics of entrepreneurs. Some authors have outlined how entrepreneurship is associated to psychological or sociological traits (Gibb, 1987 [12]; Low and MacMillan, 1988 [13]). It emerges that entrepreneurs are those who have an outstanding attitude towards leadership, risk taking and independence; furthermore, entrepreneurs have a strong need for achievement, a relevant task orientation and a high degree of tolerance of ambiguity. Yet, entrepreneurship is linked to innovation (Drucker, 1985 [14]; Kao, 1997 [15]). The concept of entrepreneur is complex and the combination of different approaches-such as the one proposed by Carland et al. (1984 [16]; 1988 [17]) that put together the trait approach with the behavioural one-could help in defining entrepreneurs. There has been a huge debate on the reliability of the models that aim to predict entrepreneurial behaviour starting from personality traits and personal characteristics (Hull et al., 1980 [18]); the literature has progressively evolved towards a classification of factors that motivate entrepreneurship into pull and push factors (Gilad and Levine, 1986 [19]). Research on ecopreneurship has followed the macro tendency shown by the wider field of entrepreneurship: there are works whose aim is to outline the distinctive traits of ecopreneurs, whilst others provide a detailed overview of push and pull ecopreneurial drivers. Background research suggests that one of the main distinctive traits of ecopreneurs is the ability to shape the face of their companies (Schaltegger, 2002 [9]; Kirkwood and Walton, 2010 [4]): the strong commitment of ecopreneurs does not remain 
theory, but it translates into management practices or organizational solutions and changes the entire business model. Emerging insights reinforce the need to adopt a behavioural perspective when studying ecopreneurs in order to see how peoples' idealistic issues influence the everyday life of a company. The relationships between personal motivations and company structure emerge from the work of Walley and Taylor (2002) [7]: their research illustrates how firms can be shaped according to the ecopreneurs' belief set and motivations.

Some authors have underlined the inner tension experienced by ecopreneurs who often must choose between making profits or going green; Linnanen (2002) [20] — by combining the desire to make money with the desire to change the world-explores how people manage the contraposition between profits and ideals. Thus, over the years, the context has changed: globally, awareness of green issues has improved; scholars have explored the existing linkages between sustainability and competitive advantage (Porter and van der Linde, 2005 [21]) and the relationships between competitive advantage and shared values (Kramer and Porter, 2011 [22]). The interest shown by Venture Capitalists towards ecopreneurs has grown over the years and it indicates the ongoing changes. Venture capitalists (VCs) have understood the benefits emerging when funding ecopreneurial activities (O'Rourke, 2010 [23]); the problems that initially arose- that were linked to VCs' requests in terms of returns and profitability that were almost impossible to meet-have been partially solved through the diffusion of a more sustainable approach to business venturing (O'Rourke, 2010 [23]). Business Angels and Venture Capitalists have changed their cultural approach and perception of environmental issues; this made market capital more accessible. Furthermore, the relationship between ecopreneurship and the profitability of the firms has changed; as emerges from the literature ( $\mathrm{O}^{\prime}$ Rourke, 2010 [23]), ethical or socially responsible investors underline social benefits.

Ecopreneurs have a strong linkage with the firms' external environment: Schaltegger (2002) [9] underlines this relationship, given ecopreneurs' ability to shape their companies from the outset. Ecopreneurs, with their behaviours, can influence the competitive environment from the outset; background research has highlighted the relational trait of green entrepreneurs and ecopreneurs as being involved in a process of making and remaking-as it is called by $\mathrm{O}^{\prime} \mathrm{Neill}$ and Gibbs (2016) [24]—that makes ecopreneurship vary temporally and spatially (O'Neill and Gibbs, 2016 [24]). Yet Houtbeckers (2016) [25] describes ecopreneurship as a mundane process that evolves over time. In their work, ecopreneurs contribute to the expansion of the green and sustainable economy and provide new solutions and practices that can be adopted by the industry. Several works have outlined the role of green entrepreneurship as a change agent (Affolderbach and Krueger, 2016 [26]; Anderson, 1998 [27]; Keogh and Polonsky, 1998 [28]; Pastakia, 1998 [29]; Walley et al., 2010 [30]). What ecopreneurs make is embedded in social relations: Anderson (1998) [27] observes that as well as entrepreneurship, environmentalism is embedded in the social context. Kirkwood and Walton (2010 [4]) highlight that the social context that ecopreneurs experience deeply influences their behaviour; furthermore, they observe that in some countries the diffusion of an environmentalist culture is more facilitated than in others.

\section{Classifications and Typologies}

Background research has provided many classifications of ecopreneurs. Ecopreneurs are different since their business motivations differ; nevertheless, the lack of empirical research that characterizes this part of the literature, contributes to presenting ecopreneurship as a static phenomenon (Fong et al., 2014 [31]). Classifications can be employed for understanding current research perspectives or for defining motivations and issues of ecopreneurs. By proposing a description of behaviours, classifications help to define a research object; this is one of the emerging aims of the work proposed by Walley and Taylor (2002) [7]. If, on one side, categories can help academicians to investigate ecopreneurs, on the other, they can limit scholars' work: this issue emerges from the work by O'Neill and Gibbs (2016) [24] who underline the risk of fixity behind proposed net categories of green entrepreneurs. 
A common trait of the works that examine the typologies of ecopreneurs is the focus on individuals; research focuses on personal motivations, beliefs and psychological traits, whilst less attention is given to the reasons that explain ecopreneurs' capability to seize opportunities (Gibbs, 2009 [32]). This trend in research reflects the structure of the conventional literature on entrepreneurship (Fong et al., 2014 [31]). The model proposed by Walley and Taylor (2002) [7] distinguishes four typologies of green entrepreneurs: innovative opportunists, visionary champions, ethical mavericks and ad hoc enviropreneurs (or environmental entrepreneurs). The authors combine the two dimensions that, in their vision, mainly shape ecopreneurship; the authors put personal orientation (motivation) in relation to the external context (structural influences). This work is remarkable not only for the proposed model but also for the continuum that emerges with the general theory on entrepreneurship (Thompson and Scott, 2010 [33]). Additionally, the authors highlight how important typologies are for the academic literature: typologies can be employed for identifying those features that better explain ecopreneurs' behaviour. Given the nature of ecopreneurs, who evolve over time, Walley and Taylor (2002) [7] suggest that a framework based on typologies should be adopted for defining the evolutionary paths of ecopreneurs. Other insights emerge from the model proposed by Linnanen (2002) [20] that put the accent on the relationship between motivations and profits; ecopreneurs can be classified as self-employed, a non-profit business, opportunists and successful idealists. The relationship between ideals and making money has been widely debated among scholars since the question "how can I combine my motivations with the need to make profits?" was posed among ecopreneurs.

Schaltegger (2010) [34] designs a framework that underlines the effects of ecopreneurs on the market: the author combines personal goals with market focus and three profiles emerge (ecopreneurs, bioneers and alternative actors). According to the priority given to sustainable issues, organizations can be more or less oriented to pursue a sustainable strategy; instead, those firms who see sustainability as the core of their business link their economic success to their firms' sustainability performance. In Schaltegger (2010) [34], the focus is on the ecopreneurial purpose to achieve considerable market share; in another work, Schaltegger and Wagner (2011) [35] underline that ecopreneurs historically focused on environmental performance rather than on social performance, and they pay less attention to sustainability performance (that combines social and environmental issues), which is seldom perceived as a core business goal.

The importance of the market when defining typologies of entrepreneurs also emerges from the work by de Bruin and Lewis (2010) [36] that correlates market orientation (from not oriented to the mass market) with green entrepreneurship response (individual, business or social); by employing this model, the authors were able to design the evolving paths of the examined companies.

One of the most cited typologies is the one proposed by Isaak (1998) [5]; this model focuses on companies' green and environmental orientation examined at the initial stage of the firms' lifecycle. Isaak (1998) [5] introduces the distinction between green business and green green business: the first typology identifies companies and entrepreneurs who adopt environmental management practices after the start-up phase; the second typology identifies those companies that were born green and that are run by entrepreneurs with a strong environmental commitment. The works by Isaak (1998 [5]; 2005 [6]) stimulate some reflection upon entrepreneurs, beginning with the role given to environmental issues when planning the firms' activity. It clearly emerges that besides the works that deal with entrepreneurs, there are other papers that focus on firms, such as the one by Freimann et al. (2005) [37] which proposes an empirical investigation on the ecological orientation of German start-up companies; according to the authors, start-ups can be classified into eco-dedicated, eco-open and eco-reluctant.

\section{Motivations}

The reasons behind ecopreneurial motivations have been deeply investigated by scholars. The traditional approach that distinguishes between push and pull factors is highly adopted in ecopreneurial studies (Kirkwood and Walton, 2010 [4]; Segal et al., 2005 [38]). 
A lot has been written on how personal motivations inspire ecopreneurs. Scholars (Kirkwood and Walton, 2010 [4]) have investigated this issue in order to find out similarities and differences between ecopreneurs and traditional entrepreneurs. The wide diffusion of environmental practices among firms has extended the debate on the "authenticity" of ecopreneurs: in some cases, entrepreneurs decide to employ environmentally friendly practices because they are forced by laws or regulatory systems. Zahraie et al. [39] analyse the role of environmental entrepreneurs in promoting and facilitating sustainability in the New Zealand wine industry; the authors clearly distinguish between ecopreneurs and winegrowers that operate on a larger scale.

Schaltegger (2002) [9] underlines how firms, in some cases, simply "manage" environmental issues; other firms instead consider environmental issues as central to their core business. Therefore, not all entrepreneurs that deal with sustainable issues can be considered as ecopreneurs. Who is an authentic ecopreneur? There is no doubt that personal attitude and motivations play a key role in shaping authentic ecopreneurs.

Background research (Kirkwood and Walton, 2010 [4]) shows that an increase in market opportunities has supported the diffusion of ecopreneurship. Many factors have contributed to improve market attractiveness for sustainable oriented firms: first of all, consumers have changed and their awareness towards environmental issues has improved (Laroche et al., 2001 [40]) with the result of creating a demand for eco-products. The segment of environmentally friendly products has registered a development in terms of size and market share (Schaltegger, 2002 [9]; Cohen and Winn, 2007 [41]), and this has attracted new ecopreneurs.

Therefore, another interesting aspect with sociological implications, is the growing aversion of some consumer segments towards Multinational or Large Corporations (Webb et al., 2008 [42]) that are seen as responsible for not adopting sustainable practices; this shared feeling has promoted the consumption of products with sustainable or green issues. In their work, Kirkwood and Walton (2010) [4] have clearly described the relationships between consumer demand for environmentally friendly products and the increasing market opportunities for firms.

The benefits of pursuing a sustainable orientation are two-fold: on one side, entrepreneurs can operate in a growing and profitable market (Schaltegger [9], 2002; Schaper, 2002 [8]); on the other side, firms can gain a competitive advantage by consolidating the company reputation (Miles and Covin, 2000 [43]; Kirkwood and Walton, 2010 [4]).

\section{A Focus on Agribusiness}

The literature that deals with the relationship between environment and agribusiness is wide and it explores many aspects, from the response to environmental issues at a country level, to the definition of performance measurement and the description of practices. A relevant part of the research focuses on the relationship between stakeholders and environmental management (see for a literature review, Reed, 2008 [44]); furthermore, there are many case studies that outline how environmentally friendly firms operate in agribusiness. However, there is a lack of research on the specific topic of ecopreneurship in agribusiness.

There is a strong linkage between entrepreneurship and agriculture (Alsos et al., 2011 [45]); from the literature, it emerges that the relationship between agriculture and entrepreneurship is at the centre of a wide debate. McElwee (2008) [46] focuses on farmers and from his work it emerges that farmers face strong barriers to becoming entrepreneurs and these barriers are greater than in other sectors. The work by McElwee (2008) [46] provides some useful insights for understanding the issue of ecopreneurship in agribusiness. First of all, the concept of agribusiness has evolved since its first introduction by Davis in 1956 [47] and it has been reframed as an approach that slowly turned from being farm centric to consumer and resource centric (Shultz and Edward, 2005) [48]; McElwee (2008) [46] underlines that the emergence of new consumer needs and the existing constraints in natural resource availability have reinforced the sustainable orientation of agribusiness. According 
to Avolio et al., 2014 [49], the linkage between the concepts of sustainability, eco-innovation and ecopreneurship in the agricultural sector clearly emerges (Avolio et al., 2014 [49]).

It must be said that agribusiness was touched by many phenomena that have improved the overall sustainable orientation within the business. First of all, pressures arising from consumer and environmental movements have reshaped the market: a sense of dissatisfaction towards industrialization has pervaded many profitable customer segments and has laid down the roots for the development of niches. Secondly, innovative technologies are available from related businesses and they can be implemented in the agrifood industry for reinforcing environmental orientation. The overall accessibility of technologies has improved, and technological solutions can be borrowed from other research fields and, then, they can be employed in agriculture. A clear example is the implementation of drones in agriculture (Anderson, 2014 [50]); drones can help firms to gain data and information that can be used for multiple purposes, including the reduction of pesticides. Resource management is one of the key issues addressed by the EU for the implementation of sustainable practices in agriculture; within this framework, technology plays a leading role (Antonopoulos et al., 2015 [51]). In Agribusiness, ecopreneurs can positively influence firms to act more sustainably (Naumes, M. J., and Kammermeyer, 2010 [52]).

The relationship between ecopreneurs and technology has been investigated. Most of the research has focused on the role that ecopreneurs, seen as change agents, have in the diffusion of innovation: Pastakia (1998 [29]) underlines that ecopreneurs are individuals that seek to promote eco-friendly ideas/products/technology. From the literature, we do not have any insights into the ability of ecopreneurs to borrow technology from related or other fields, and, then, to develop new industry solutions. In fact, in the literature, there are many cases that describe the development of new technologies applied to agribusiness (see, among others, Pastakia, 1998 [29]), but it is hard to find empirical articles that investigate the process that leads to technology implementation and development; it is even harder to find papers that outline the peculiarities of ecopreneurs who are committed to developing new technologies in agribusiness. Most of the considerations that can be drawn from the literature remain at a general level. According to the World Business Council for Sustainable Development (WBCSD, 2010 [53]; Indaco-Patters et al., 2013 [54]), ecopreneurs are key drivers (Indaco-Patters et al., 2013 [54] call them catalysts) of innovation, and they promote a change from a business vision based on the exploitation of natural resources, to one that is based on resource preservation.

Ecopreneurs who operate in agribusiness, also find a breeding ground for the development of new technologies, due to market and industry pressures for assuring food quality, safety and consumer trust; these elements, combined with the emerging interest for environmental control, have been supported by organizations and institutions, and, consequently they have shaped ecopreneurs (Antonopoulos et al., 2015 [51]).

Food and agribusiness industries are characterized by a strong interest towards eco innovation activities, such as the implementation of cleaner and more efficient processes, recycling, waste and water management, etc. (Cuerva et al., 2014 [55]). SMEs have been at the centre of this "greening process", since SMEs are highly adaptable and have a strong attitude to understanding local markets (Moore and Manring, 2009 [56]; Cuerva et al., 2014 [55]).

Market conditions are drivers for ecopreneurship in agriculture. There is a wide consensus about the positive role that consumers have in the development of a market for sustainable products.

An interesting issue emerges from the works by Cuerva et al. (2014 [55]) and Hockerts and Wustenhagen (2010 [57]), who highlight how the development in the retailing industry has promoted the birth of small shops that specialize in natural or eco-friendly products. The growing interest of consumers towards these kinds of food products has supported entrepreneurs to grow and sell products characterized by ethical issues (Holt, 2012 [58]). In their article, Cuerva et al. (2014 [55]), by focusing on the UK market, point out some questions that still remain open and that are valid for other countries: Will ecopreneurship in the food sector help deliver a sustainable future? How will 
ecopreneurs deliver quality produce alongside demands for cheaper and more processed foods in the supermarkets? What motivations, personal development skills and managerial qualities are required for future ecopreneurs in a highly competitive sector?

Lasner and Hamm (2011) [59], in an empirical investigation on pioneer ecopreneurs in aquaculture, point out that the drivers that have promoted an ecopreneurial approach to the business were the ongoing deployment of natural resources, the demand for the market and the interest in growth shown by institutions and policy makers. Thus, the ecopreneurs examined vary in terms of personal commitment and approach to technical issues and problems. The authors show that economic uncertainty and prejudice towards organic methods can negatively affect ecopreneurial diffusion in the considered sector; on the other side, organizations can be catalysts for the development of ecopreneurship when involved in disseminating the results of positive impacts of a sustainable approach to business. Nevertheless, working on the reinforcement of the linkages and differences between traditional and innovative methods could be extremely helpful, since it emerges from the research that the lack of detailed information about sustainable practices-that in some cases derive from a learning by doing experience-can negatively affect the diffusion of a sustainable approach within the business. This is also confirmed by researches carried out in other businesses: in the wine business, scholars (Santini et al., 2013 [60]) have shown that the development of a shared "handbook" of sustainable practices realized by entrepreneurs had a positive impact on the diffusion of a sustainable orientation among wine firms in California.

\section{Ecopreneurship and Traditional Entrepreneurship}

Since many authors define ecopreneurship as a mix between ecological issues and entrepreneurship (see, among others, Schaltegger, 2002 [9]), they tend to find in ecopreneurs traits that are more or less developed than in traditional entrepreneurship.

There are many works that explore the differences between traditional entrepreneurship and ecopreneurship. The thematic is controversial and it is hard to provide an answer: in his work, Linnanen (2005) [61] writes: "Is environmental entrepreneurship something different from ordinary entrepreneurship? The right answer might be both no and yes. Most of the normal entrepreneurial laws, such as the correlation between risk and profit, the right timing for market entry and the need for adequate financial and human capital are valid also in environmental ventures. To be successful, environmental entrepreneurs should move fast, motivate others and take risks as well as anticipate and supply what large numbers of people want. However, the values-based leadership often rightly associated with environmental entrepreneurs gives a special flavour to these businesses." (p. 110). There is no doubt that the answer to the above questions also depends on the authors' approach to ecopreneurship. This also clearly emerges from the work by Phillips (2005) [62], who finds, in the tension that ecopreneurs experience between their values and current constructions of entrepreneurship, one of the main differences between ecopreneurship and entrepreneurship; those who see in entrepreneurs a strong orientation towards maximizing profits (Friedman and Phillips, 2003 in Phillips, 2005 [62]), recognize in ecopreneurs a less materialistic attitude. Ecopreneurs feel not only the pressure of financials, but also the need to make their business vision accepted by the majority of the population (Zahraie, 2016 [39]).

Hence, since the market opportunities linked to environmental products are growing, the opportunities that ecopreneurs have to make profits are higher; as a consequence, due to changes happening in this context, an excessive focus on this aspect might create misunderstanding.

Ecopreneurship can be considered as one of the typologies within the entrepreneurship domain (Schaper, 2002 [8]): in this sense, ecopreneurs distinguish themselves through their highly environmentally responsible business practices and values.

Some authors (Dixton and Clifford, 2007 [63]) have underlined ecopreneurs' ability to establish relationships with multiple stakeholders; relationships enable the company to pursue a strategy based on environmental values. 
Another distinctive trait is that ecopreneurs must adopt a social perspective when considering the innovative solution that they propose: ecopreneurs are often responsible for the introduction of breakthrough innovation and they need to be more aware of underlining the social aspects of their work than traditional entrepreneurs (Schaltegger and Wagner, 2011 [35]).

The commitment shown by ecopreneurs not only facilitates the introduction of radical ecological innovation, but it also helps ecopreneurs to recognize as opportunities situations that other entrepreneurs would define as of low interest (Keogh and Polonsky, 1998 [28], pp. 40, 42). Ecopreneurs can act as facilitators of change and they contribute to creating new institutions and structures in their industry; this clearly emerges from the work of Zahraie et al. (2016) [39].

Some authors (Schaltegger, 2002 [9]) underline that ecopreneurs are more focused on personal initiatives and skills rather than having developed an interest towards management systems or technical procedures. Thus, the adoption of a wide market perspective implies the development of managerial skills. The work by Rodgers (2010) [64] focuses on the abilities and skills that ecopreneurs must possess; besides those traits that in ecopreneurs are more accentuated than in traditional entrepreneurs, some novelty emerges in terms of the perception of benefits being based on the idea of well-being rather than on economic principles; also, a deep attention to lifestyle and to pursuing economic activities that preserve what is good for themselves distinguishes ecopreneurs.

It is hard to outline traits that exclusively belong to ecopreneurs and not to traditional entrepreneurs; going back to the provocative question posed by Linnanen (2005) [61], we can say that ecopreneurs have in their DNA an openness towards ecological and social responsibilities.

The systematic integration of sustainability in the set of cultural values that belong to entrepreneurs is the main feature that characterizes ecopreneurs.

Another important issue is that co-creation is a key issue in ecopreneurship; co-creation is characterized by a high degree of creativity, collaboration and by a societal orientation. From a marketing perspective, co-creation is opposite to customization (Kristensson et al., 2008 [65]) and fits perfectly with ecopreneurs' business approach.

The work by Edgeman (2015 [66]) outlines that firms and ecopreneurs must face wicked global challenges (climate changes and global warming; extreme weather events, drought and desertification; food availability and distribution; pollution; human diseases in general); the paper highlights situations and examples that depict how firms approach sustainability; as a consequence, ecopreneurs must have the ability to employ several tools in order to face wicked challenges and to perform a critical analysis of information. Ecopreneurs need to recognize the need for data analysis and information and to be open to employing sophisticated data analytic capabilities within their companies (Edgeman, 2015 [66]).

The work by Gallagher (2012) [67] includes part of an interview with an ecopreneur who declares, "You must have the standard entrepreneurship aspect down before you can add the eco aspect" (p. 175).

\section{Discussion and Conclusions}

The issue of ecopreneurship is progressively attracting many scholars. What emerges from the literature is that there are many works that provide theoretical contributions, but fewer empirical researches have been carried out. There are many reasons behind the lack of empirical research; first of all, it is difficult to draw the boundaries of ecopreneurship and this represents a first barrier to overcome. Thus, besides the huge efforts expended in defining ecopreneurship and exploring its features, the impression is that the research has floundered at a theoretical level of the debate. Empirical researches would represent significant progress towards the diffusion of a grounded theory approach to the study of ecopreneurship. Moreover, the first step could be the implementation of empirical research based on available models; further development of case studies and empirical investigations on a larger scale would significantly improve this research field. The grounded theory approach has been employed by some scholars in their work on ecopreneurship (Gilstrap and Gilstrap in Gallagher, 2012 [67]; Lasner and Ulrich, 2014 [68]) for understanding ecopreneurial traits or for 
defining typologies of ecopreneurs. Yet, further steps for the development of a grounded theory based approach to ecopreneurship should be made.

As we have highlighted in this paper, a relevant part of the literature has aimed to define typologies and categories of ecopreneurs, whilst fewer attempts have been made to employ emerging typologies within the analysis of a set of data. We have highlighted the existing differences among typologies of green entrepreneurs (see, among others, Isaak, 2005 [6]) and the development of studies that analyse the strategic implications of a sustainable orientation for companies (see, among others, Santini et al., 2013 [60]; Casini et al., 2010 [69]) have also raised another question: is it possible to conceive a development path for ecopreneurs? Further research should be conducted in this direction, too; such a trend in research would help to confer dynamicity to this niche of studies. Given the growing competitiveness in the sustainable agrifood industry, it is appropriate to suppose that ecopreneurs, along with their strategies, will change in order to face new market challenges and needs. A reflection on skills and competences is appropriate: there is no doubt that motivations play a key role, but when a degree of competitiveness arises, competences become key issues. A new research question will soon emerge: how to employ motivation in the definition of a set of unique skills and competences?

As for the differences between ecopreneurs and traditional entrepreneurs, the matter is still open. Background research has highlighted that in ecopreneurs some traits that characterize traditional entrepreneurs are emphasized. From the literature, it emerges that new researches should be carried out in order to further explore the insights of the last fifteen years in academia.

It can be said that even if the academic debate is booming, research is still at its embryo stage in some areas of ecopreneurship. On the other hand, we must also underline that many scholars suggest academicians expend their time and efforts carrying out empirical researches.

From our research, it also emerges that some investigations should be carried out at an intersectorial level: beside the fact that it is clear that differences occur at a country level, it would be interesting to understand what happens among sectors. In this paper, we have underlined the dynamics of ecopreneurship in agribusiness; the starting point was the clear linkage between agribusiness and ecopreneurship. Thus, it would be useful to investigate how sector dynamics affect the birth of ecopreneurship and if the differences perceived among sectors in terms of degree of innovativeness have a similar echo within the ecopreneurship sphere. The debate on ecopreneurship seems to have solid bases for development in the coming years and for evolution in multiple directions.

Conflicts of Interest: The author declares no conflict of interest.

\section{References}

1. Hart, C. Doing a Literature Review: Releasing the Social Science Research Imagination; Sage: London, UK, 1998.

2. Jesson, J.; Matheson, L.; Lacey, F.M. Doing Your Literature Review: Traditional and Systematic Techniques; Sage: London, UK, 2011.

3. Chell, E.; Haworth, J.M.; Brearley, S. The Entrepreneurial Personality: Concepts, Cases, and Categories; Routledge: London, UK, 1991.

4. Kirkwood, J.; Walton, S. What motivates ecopreneurs to start businesses? Int. J. Entrep. Behav. Res. 2010, 16, 204-228. [CrossRef]

5. Isaak, R. Green Logic: Ecopreneurship, Theory and Ethics; Greenleaf: Sheffield, UK, 1998.

6. Isaak, R. The making of the ecopreneur. In Making Ecopreneurs: Developing Sustainable Entrepreneurship; Schaper, M., Ed.; Gower Publishing: Surrey, UK, 2010; pp. 13-26.

7. Walley, E.E.; Taylor, D.W. Opportunists, Champions, Mavericks ... ? Greener Manag. Int. 2002, 38, 31-44. [CrossRef]

8. Schaper, M. The challenge of environmental responsibility and sustainable development: Implications for SME and entrepreneurship academics. In Radical Changes in the World: Will SMEs Soar or Crash? Füglistaller, U., Pleitner, H.J., Volery, T., Weber, W., Eds.; University of St Gallen KMU-HSG: St. Gallen, Switzerland, 2002; pp. 541-553.

9. Schaltegger, S. A framework for ecopreneurship. Greener Manag. Int. 2002, 38, 45-59. [CrossRef] 
10. Hockerts, K. Introduction to Part IV-Ecopreneurship: Unique Research Field or Just 'More of the Same'? In Social Entrepreneurship; Mair, J., Robinson, J., Hockerts, K., Eds.; Palgrave: Macmillan, UK, 2006; pp. 209-213.

11. Isaak, R. Ecopreneurship, rent-seeking, and free-riding in global context: Job-creation without ecocide. Small Entrep. Res. 2016, 23, 85-93. [CrossRef]

12. Gibb, A.A. Enterprise culture-Its meaning and implications for education and training. J. Eur. Ind. Train. 1987, 11, 3-38.

13. Low, M.B.; MacMillan, I.C. Entrepreneurship: Past research and future challenges. J. Manag. 1988, 14, 139-161.

14. Drucker, P. How to make people decisions. Harv. Bus. Rev. 1985, 63, 22-25.

15. Kao, R.W. An Entrepreneurial Approach to Corporate Management; Prentice Hall: Upper Saddle River, NJ, USA, 1997.

16. Carland, J.W.; Hoy, F.; Boulton, W.R.; Carland, J. Differentiating Entrepreneurs from Small Business Owners: A Conceptualization. Acad. Manag. Rev. 1984, 9, 354-359.

17. Carland, J.W.; Hoy, F.; Carland, J.A.C. Who is an entrepreneur? Is a question worth asking. Am. J. Small Bus. 1988, 12, 33-39.

18. Hull, D.; Bosley, J.; Udell, G. Renewing the Hunt for the Heffalump: Identifying potential entrepreneurs by personality characteristics. J. Small Bus. Manag. 1980, 18, 11-18.

19. Gilad, B.; Levine, P. A. Behavioral model of entrepreneurial supply. J. Small Bus. Manag. 1986, 24, 45-54.

20. Linnanen, L. An Insider's Experiences with Environmental Entrepreneurship. Greener Manag. Int. 2002, 38, 71-80. [CrossRef]

21. Porter, M.E.; Linde, C.V.D. Green and competitive: Ending the stalemate. J. Bus. Adm. Policy Anal. 1999, 215-221.

22. Kramer, M.R.; Porter, M. Creating shared value. Harv. Bus. Rev. 2011, 89, 62-77.

23. O'Rourke, A.R. How Venture Capital Can Help. In Making Ecopreneurs: Developing Sustainable Entrepreneurship; Schaper, M., Ed.; Gower Publishing: Surrey, UK, 2010; pp. 165-178.

24. O'Neill, K.; Gibbs, D. Rethinking green entrepreneurship-Fluid narratives of the green economy. Environ. Plan. A 2016, 48, 1727-1749. [CrossRef]

25. Houtbeckers, E. The tactics of ecopreneurs aiming to influence existing practices. Small Enterp. Res. 2016, 23, 22-38. [CrossRef]

26. Affolderbach, J.; Krueger, R. "Just" ecopreneurs: Re-conceptualising green transitions and entrepreneurship. Local Environ. 2016, 22, 1-14. [CrossRef]

27. Anderson, A.R. Cultivating the Garden of Eden: Environmental entrepreneuring. J. Chang. Manag. 1998, 11, 135-144. [CrossRef]

28. Keogh, P.D.; Polonsky, M.J. Environmental commitment: A basis for environmental entrepreneurship? J. Organ. Chang. Manag. 1998, 11, 38-49. [CrossRef]

29. Pastakia, A. Grassroots ecopreneurs: Change agents for a sustainable society. J. Organ. Chang. Manag. 1998, 11, 157-173. [CrossRef]

30. Walley, L.; Taylor, D.; Greig, K. Beyond the visionary champion: Testing a typology of green entrepreneurs. In Making Ecopreneurs: Developing Sustainable Entrepreneurship; Schaper, M., Ed.; Gower Publishing Limited: Surrey, UK, 2010; pp. 59-74.

31. Fong, N.; Wolfgramm, R.; Shepherd, D. Ecopreneurs as change agents; opportunities, innovations and motivations. Q. J. Econ. 2014, 84, 488-500.

32. Gibbs, D. Sustainability entrepreneurs, ecopreneurs, and the development of a sustainable economy. Greener Manag. Int. 2009, 55, 63-78. [CrossRef]

33. Thompson, J.L.; Scott, J.M. Environmental entrepreneurship: The sustainability challenge. In Proceedings of the Institute of Small Business and Entrepreneurship Conference (ISBE), London, UK, 3-4 November 2010; ISBE: London, UK, 2010.

34. Schaltegger, S. A framework and typology. In Making Ecopreneurs: Developing Sustainable Entrepreneurship; Schaper, M., Ed.; Gower Publishing: Surrey, UK, 2010; pp. 75-84.

35. Schaltegger, S.; Wagner, M. Sustainable entrepreneurship and sustainability innovation: Categories and interactions. Bus. Strateg. Env. 2011, 20, 222-237. [CrossRef] 
36. De Bruin, A.; Lewis, K. Green entrepreneurship in New Zealand: A micro-enterprise focus. In Making Ecopreneurs: Developing Sustainable Entrepreneurship; Schaper, M., Ed.; Gower Publishing: Surrey, UK, 2010; pp. 95-108.

37. Freimann, J.; Marxen, S.; Schick, H. Sustainability in the start-up process. In Making Ecopreneurs: Developing Sustainable Entrepreneurship; Schaper, M., Ed.; Gower Publishing: Surrey, UK, 2010; pp. 149-164.

38. Segal, G.; Borgia, D.; Schoenfeld, J. The motivation to become an entrepreneur. Int. J. Entrep. Behav. Res. 2005, 11, 42-57. [CrossRef]

39. Zahraie, B.; Everett, A.M.; Walton, S.; Kirkwood, J. Environmental entrepreneurs facilitating change toward sustainability: A case study of the wine industry in New Zealand. Small Enterp. Res. 2016, 23, 39-57. [CrossRef]

40. Laroche, M.; Bergeron, J.; Barbaro-Forleo, G. Targeting consumers who are willing to pay more for environmentally friendly products. J. Consum. Mark. 2001, 18, 503-520. [CrossRef]

41. Cohen, B.; Winn, M.I. Market imperfections, opportunity and sustainable entrepreneurship. J. Bus. Ventur. 2007, 22, 29-49. [CrossRef]

42. Webb, D.J.; Mohr, L.A.; Harris, K.E. A re-examination of socially responsible consumption and its measurement. J. Bus. Res. 2008, 61, 91-98. [CrossRef]

43. Miles, M.P.; Covin, J.G. Environmental marketing: A source of reputational, competitive, and financial advantage. J. Bus. Ethics 2000, 23, 299-311. [CrossRef]

44. Reed, M.S. Stakeholder participation for environmental management: A literature review. Biol. Conserv. 2008, 141, 2417-2431. [CrossRef]

45. Alsos, G.A.; Carter, S.; Ljunggren, E. (Eds.) The Handbook of Research on Entrepreneurship in Agriculture and Rural Development; Edward Elgar Publishing: Northampton, MA, USA, 2011.

46. McElwee, G. A taxonomy of entrepreneurial farmers. Int. J. Entrep. Small Bus. 2008, 6, 465-478. [CrossRef]

47. Davis, J.H. From agriculture to agribusiness. Harv. Bus. Rev. 1956, 34, 107-115.

48. Shultz, C.J.; Edwards, M.R. Reframing agribusiness: Moving from farm to market centric. J. Agribus. 2005, 23, 57-73.

49. Avolio, G.; Blasi, E.; Cicatiello, C.; Franco, S. The drivers of innovation diffusion in agriculture: Evidence from Italian census data. J. Chain Netw. Sci. 2014, 14, 231-245. [CrossRef]

50. Anderson, C. Agricultural Drones: Relatively Cheap Drones with Advanced Sensors and Imaging Capabilities are Giving Farmers New Ways to Increase Yields and Reduce Crop Damage. MIT Technol. Rev. 2014, 17, 3-58.

51. Antonopoulos, I.; Canfora, P.; Dri, M.; Gaudillat, P.; Styles, D.; Williamson, J.; Jewer, A.; Haddaway, N.; Price, M. Best Environmental Management Practice for the Agriculture Sector-Crop and Animal Production. Available online: http://susproc.jrc.ec.europa.eu/activities/emas/documents/AgricultureBEMP.pdf (accessed on 18 September 2016).

52. Naumes, M.J.; Kammermeyer, J.A. Sustainable Harvest International: Creating local ecopreneurs. In Making Ecopreneurs: Developing Sustainable Entrepreneurship; Schaper, M., Ed.; Gower Publishing: Surrey, UK, 2010; pp. 239-251.

53. WBCSD. Available online: http://www.wbcsd.org/ (accessed on 20 September 2016).

54. Indaco-Patters, S.; Fearon, C.; Nolan, C.; Warden, K. Micro-ecopreneurs and the UK food industry: Short-term fad or sustainable reality? Ind. Commer. Train. 2013, 45, 330-335.

55. Cuerva, M.C.; Triguero-Cano, Á.; Córcoles, D. Drivers of green and non-green innovation: Empirical evidence in Low-Tech SMEs. J. Clean. Prod. 2014, 68, 104-113.

56. Moore, S.B.; Manring, S.L. Strategy development in small and medium sized enterprises for sustainability and increased value creation. J. Clean. Prod. 2009, 17, 276-282. [CrossRef]

57. Hockerts, K.; Wüstenhagen, R. Greening Goliaths versus emerging Davids-Theorizing about the role of incumbents and new entrants in sustainable entrepreneurship. J. Bus. Ventur. 2010, 25, 481-492. [CrossRef]

58. Holt, D.B. Constructing sustainable consumption from ethical values to the cultural transformation of unsustainable markets. Ann. Am. Acad. Political Soc. Sci. 2012, 644, 236-255. [CrossRef] 
59. Lasner, T.; Hamm, U. Ecopreneurship in Aquaculture-The adoption of organic fish farming methods. In Organic Is Life Knowledge for Tomorrow. Volume 2-Socio-Economy, Livestock, Food Quality, Agro-Ecology and Knowledge Dissemination, Proceedings of the Third Scientific Conference of the International Society of Organic Agriculture Research (ISOFAR), 17th IFOAM Organic World Congress, Namyangju, Korea Republic, 28 September-1 October 2011; ISOFAR: Trenthorst, Germany, 2011; pp. 72-75.

60. Santini, C.; Cavicchi, A.; Casini, L. Sustainability in the wine industry: Key questions and research trends. Agric. Food Econ. 2013, 1, 1. [CrossRef]

61. Linnanen, L. An insider's experiences with environmental entrepreneurship. In Making Ecopreneurs: Developing Sustainable Entrepreneurship; Schaper, M., Ed.; Gower Publishing: Surrey, UK, 2010; pp. 72-88.

62. Phillips, M. Ecopreneurs making (green) sense: Reflections on two case studies. In Proceedings of the British Academy of Management Conference, Oxford, UK, 13-15 September 2005; Volume 2A. Available online: http://www.bris.ac.uk/efm/people/mary-e-phillips/pub/1971326 (accessed on 15 September 2016).

63. Dixon, S.E.A.; Clifford, A. Ecopreneurship-A new approach to managing the triple bottom line. J. Organ. Chang. Manag. 2007, 20, 326-345. [CrossRef]

64. Rodgers, C. Understanding "SustainAbilities": An Exploration of the Skills and Traits of Ecopreneurs in Sustainable Entrepreneurship. In Proceedings of the 2010 Corporate Responsibility Research Conference, Marseille, France, 15-17 September 2010; Available online: http://www.crrconference.org/Previous_ conferences/downloads/crrc2010rodgers.pdf (accessed on 15 September 2016).

65. Kristensson, P.; Matthing, J.; Johansson, N. Key strategies for the successful involvement of customers in the co-creation of new technology-based services. Int. J. Serv. Ind. Manag. 2008, 19, 474-491. [CrossRef]

66. Edgeman, R. Wicked global challenges: Sustainability in the enterprise crosshairs. Meas. Bus. Excell. 2015, 19, 13-23. [CrossRef]

67. Gallagher, D.R. (Ed.) Environmental Leadership: A Reference Handbook; Sage: London, UK, 2012.

68. Lasner, T.; Ulrich, H. Exploring Ecopreneurship in the Blue Growth: A Grounded Theory Approach. Roc. Socjol. Mor. 2014, 23, 4-20.

69. Casini, L.; Cavicchi, A.; Corsi, A.; Santini, C. Hopelessly devoted to sustainability: Marketing challenges to face in the wine business. In Proceedings of the 119th EAAE Seminar 'Sustainability in the Food Sector: Rethinking the Relationship between the Agro-Food System and the Natural, Social, Economic and Institutional Environments, Capri, Italy, 30 June-2 July 2010.

(C) 2017 by the author. Licensee MDPI, Basel, Switzerland. This article is an open access article distributed under the terms and conditions of the Creative Commons Attribution (CC BY) license (http:/ / creativecommons.org/licenses/by/4.0/). 